\title{
BTL SEBAGAI UPAYA MENINGKATKAN AKTIVITAS DAN HASIL BELAJAR MATERI CAHAYA
}

\author{
Abdul Rochim
}

\section{ABSTRAK}

Tujuan penelitian ini adalah untuk meningkatkan aktivitas dan hasil belajar fisika materi cahaya melalui model pembelajaran Better Teaching and Learning (BTL) bagi peserta didik kelas VIII G SMP 1 Kudus Tahun Pelaja$\operatorname{ran} 2011 / 2012$

Penelitian ini dilakukan dengan mengambil subyek peserta didik kelas VIII G SMP 1 Kudus sejumlah 26 anak terdiri dari 14 anak laki-laki dan 12 anak perempuan, dimana peneliti sebagai guru IPA (fisika) pada kelas tersebut. Penelitian ini dilakukan selama 5 bulan dari bulan Maret 2012 sampai bulan Juni 2012.

Metode yang digunakan dalam penelitian ini adalah penelitian tindakan kelas yang terdiri dari 2 siklus, masing-masing siklus terdiri dari 4 tahapan yaitu perencanan (planning), pelaksanaan (acting), pengamatan (observing) dan refleksi (reflecting). Pada siklus 1 tindakan yang dilakukan dengan model pembelajaran BTL dengan menitikberatkan lembar kerja terbimbing sedangkan pada siklus 2 tindakan yang dilakukan dengan model pembelajaran BTL dengan menitikberatkan lembar kerja terbuka dan pemanfaatan lingkungan sebagai sumber belajar.

Hasil penelitan menunjukkan bahwa secara teoritik dan empirik melalui model pembelajaran BTL dapat meningkatkan aktivitas dan hasil belajar fisika materi cahaya bagi peserta didik kelas VIII G SMP 1 Kudus pada semester 2 tahun 2011/2012. Peningkatan aktivitas belajar fisika sebesar 49\% dari kondisi awal 64 menjadi 94. Sedangkan Peningkatan hasil belajar fisika sebesar $22 \%$ dari kondisi awal 72 menjadi 88 .

Kata Kunci: Aktivitas belajar, Hasil belajar, Model Pembelajaran BTL 


\section{PENDAHULUAN}

Pelajaran Ilmu Pengetahuan Alam (IPA) berkaitan dengan cara mencari tahu tentang alam secara sistematis sehingga IPA bukan hanya penguasaan kumpulan pengetahuan yang berupa faktafakta, konsep-konsep, atau prinsip-prinsip saja, tetapi juga merupakan suatu proses penemuan. Pendidikan IPA diharapkan dapat menjadi wahana bagi peserta didik untuk mempelajari diri sendiri dan alam sekitar, serta prospek pengembangan lebih lanjut dalam menerapkannya di dalam kehidupan sehari-hari. Proses pembelajarannya menekankan pada pemberian pengalaman langsung untuk mengembangkan kompetensi agar menjelajahi dan memahami alam sekitar secara ilmiah. Pendidikan IPA diarahkan untuk inkuiri dan berbuat sehingga dapat membantu peserta didik untuk memperoleh pemahaman yang lebih mendalam tentang alam sekitar (Permendiknas 23 tahun 2006).

Kondisi di lapangan menunjukkan bahwa pelajaran Ilmu Pengetahuan Alam (IPA), khususnya materi Fisika, dirasakan sebagai pelajaran yang sulit dan membosankan. Fisika dianggap sebagai pelajaran yang sulit karena banyak teori dan rumus sehingga kurang dapat dipahami. Hal ini ditunjukkan dengan hasil ulangan harian siswa terhadap mata pelajaran Fisika yang belum mencapai tuntas belajar. Nilai KKM mata pelajaran Fisika sebesar 80. Hasil nilai ratarata ulangan harian 72 dan siswa yang telah tuntas belajar sebanyak $70 \%$. Pencapaian nilai KKM dilakukan dengan remedial teaching dan remedial testing. Kenyataan lain dalam kegiatan belajar mengajar fisika, umumnya siswa menampakkan sikap kurang bergairah, kurang bersemangat, dan kurang siap menerima pelajaran sehingga motivasi belajar siswa juga sangat rendah. Ditandai dengan persentase aktivitas belajar siswa hanya sebesar $64 \%$.

Saat menghadapi ujian nasional seringkali guru harus mengulang lagi pelajaran di kelas sebelumnya. Catatan peneliti setiap kali mereview pokok bahasan sebelumnya, terutama di jenjang kelas di bawahnya, terlihat siswa kurang begitu menguasai materi tersebut. Bahkan seakan-akan materi tersebut, belum diajarkan sebelumnya. Laporan Analisis Ujian Nasional Tahun 2011 oleh BSNP menunjukkan, daya serap pada SKL jenjang kelas VII, menentukan massa je- 
nis benda sebesar 54,01\% begitu juga dengan SKL jenjang kelas VIII, menentukan besaran pada alat optik sebesar $64,54 \%$. Daya serap SKL jenjang kelas IX, menentukan jenis muatan listris statis sebesar $92,36 \%$. Hal ini menunjukkan besar persentase siswa yang menjawab benar pada SKL pada jenjang kelas VII dan kelas VIII tersebut relatif lebih rendah dibandingkan dengan SKL pada jenjang kelas IX. Kemampuan mempertahankan kualitas penguasaan konsep yang tersimpan pada longterm memory siswa sangat minimal. Hal ini dikarenakan proses belajar mengajar yang dialami siswa kurang bermakna bagi mereka.

Kenyataan ini mendorong peneliti untuk melakukan perbaikan pembelajaran agar dapat membangkitkan motivasi dan kebermaknaan belajar siswa. Guru menumbuhkan keyakinan siswa bahwa sebenarnya mereka telah belajar fisika sepanjang hari dengan tanpa disadarinya. Di samping itu, guru juga melibatkan siswa dalam kegiatan belajar mengajar. Dengan melibatkan aktivitas siswa, diharapkan siswa mampu menemukan kebermaknaan suatu proses pembelajaran sehingga diharapkan kualitas konsep yang tersimpan dalam logterm memory-nya meningkat.

Model pembelajaran Better Teaching and Learning (BTL) yang awalnya merupakan materi pelatihan yang dilaksanakan oleh Desentralized Base Education (DBE3) dan dibiayai oleh United State of America International Development (USAID) dengan nama Pengajaran Profesional dan Pembelajaran Bermakna namun lebih dikenal dengan istilah BTL yang merupakan paket pelatihan yang menitikberatkan pada life skill for youth dengan sasaran jenjang pendidikan tingkat SMP. BTL dikembangkan berdasarkan kenyataan di lapangan bahwa pembelajaran kurang memberdayakan siswa, dalam proses belajar mengajar.

Keterampilan proses sains pada pembelajaran fisika merupakan manipulasi pembelajaran sehingga siswa dapat menemukan sendiri fakta-fakta, membangun konsep dan teori dengan keterampilan intelektual dan sikap ilmiah siswa sendiri sejalan dengan model pembelajaran BTL. Pengenalan model pembelajaran BTL ini perlu disebarluaskan dan dikembangkan lebih lanjut disesuaikan dengan kebutuhan mata pelajaran IPA, khususnya materi Fisika. 
Keefektifan penerapan model pembelajaran BTL secara akademik juga perlu diteliti.

Berdasarkan uraian di atas maka rumusan masalah dalam penelitian ini adalah: (1) Bagaimana peningkatan aktivitas belajar materi cahaya pada peserta didik kelas VIII G SMP 1 Kudus setelah dibelajarkan dengan model pembelajaran BTL, Dan (2) Bagaimana peningkatan hasil belajar materi cahaya pada peserta didik kelas VIII G SMP 1 Kudus setelah dibelajarkan dengan model pembelajaran BTL?

Sedangkan tujuan penelitian adalah: (1) Peningkatan aktivitas belajar materi cahaya pada peserta didik kelas VIII G SMP 1 Kudus setelah dibelajarkan dengan model pembelajaran BTL, dan (2) Peningkatan hasil belajar materi cahaya pada peserta didik kelas VIII G SMP 1 Kudus setelah dibelajarkan dengan model pembelajaran BTL.

Adapun manfaat Penelitian (1) bagi peserta didik adalah: dapat meningkatnya aktivitas dan hasil belajar fisika Manfaat bagi peneliti, (2) bagi Peneliti: Melalui model pembelajaran BTL dapat meningkatkan aktivitas dan hasil belajar materi cahaya pada peserta didik kelas VIII G SMP 1 Kudus, dan (3) bagi sekolah adalah: meningkatnya prestasi sekolah dan hasil Ujian Nasional mata pelajaran IPA.

\section{LANDASAN TEORI}

\section{Model Pembelajaran BTL}

Model pembelajaran BTL yang awalnya merupakan paket pelatihan yang dilaksanakan oleh Decentralized Basic education 3 (DBE3) Project, yang dibiayai USAID yang bertujuan untuk mendukung Departemen Pendidikan Nasional dan Departemen Agama dalam meningkatkan mutu dan relevansi pendidikan menengah pertama dan pendidikan non formal. Paket pelatihan ini bernama Pengajaran Profesional dan Pembelajaran Bermakna dan lebih diperjelas lagi dengan nama Priktik Mengajar yang Baik, namun lebih dikenal dengan istilah BTL yang merupakan paket pelatihan yang menitikberatkan pada life skill for youth dengan sasaran jenjang pendidikan tingkat SMP.

BTL dikembangkan berdasarkan kenyataan di lapangan bahwa 
pembelajaran kurang memberdayakan peserta didik dalam proses belajar mengajar. Peserta didik hanya sebagai obyek pembelajaran, aktivitas belajar peserta didik kurang optimal dan media pembelajaran kurang termanfaatkan oleh peserta didik. Pendekatan yang dipakai dalam model pembelajaran BTL ini meliputi lima unsur kunci dari pengalaman pembelajaran yaitu Introduction (Kenalkan), Connection (Hubungkan), Application (Terapkan), Reflection (Refleksi), dan Extension (Kegiatan Lanjutan). Penggunaan kerangka ICARE dimaksudkan untuk memastikan bahwa para peserta didik memiliki kesempatan untuk mengaplikasikan apa yang telah mereka pelajari (Tim Penyusun DBE3, 2009).

Proses pembelajaran BTL mengintegrasikan keterampilanketerampilan yang dapat memberdayakan peserta didik meliputi pertanyaan tingkat tinggi, pembelajaran kooperatif, pemanfaatan lingkungan kelas, lembar kerja, dan pemanfaatan media belajar.

\section{Aktivitas Belajar}

Aktivitas belajar peserta didik yang diharapkan dalam model pembelajaran BTL antara lain sebagai berikut.

1. Pertanyaan tingkat tinggi, kegiatan yang terlibat berupa kegiatan mendengarkan dan menulis pertanyaan, serta oral dalam menjawab pertanyaan.

2. Pemecahan masalah, kegiatan yang terlibat berupa kegiatan mendengarkan, menulis, bekerja dengan alat visual, mempelajari masalah, mengapresiasi literatur dan menyajikan informasi.

3. Pembelajaran kooperatif, kegiatan yang terlibat berupa kegiatan mendengarkan, oral untuk berkomunikasi, visual, mental dan emosional.

4. Pemanfaatan lingkungan kelas, kegiatan yang terlibat berupa kegiatan visual, fisik, emosional, kontruksi, eksekusi dan trip.

5. Lembar kerja, kegiatan yang terlibat berupa kegiatan visual, mempelajari masalah, eksekusi, mengapresiasi literatur, dan menyajikan informasi.

6. Pemanfaatan media pembelajaran, kegiatan yang terlibat berupa kegiatan visual, oral, mental, emosional. 


\section{Kerangka Berpikir}

Dalam pembelajaran, aktivitas dan hasil belajar peserta didik merupakan hal yang sangat penting. Proses pembelajaran yang mengoptimalkan seluruh aktivitas peserta didik akan berdampak kepada kebermaknaan dan longterm memory peserta didik meningkat, dan pada akhirnya hasil belajar juga akan meningkat.

Pada kondisi awal, proses pembelajaran yang telah dilakukan menunjukkan aktivitas dan hasil belajar peserta didik rendah. Supaya aktivitas dan hasil belajar peserta didik meningkat maka guru dalam pembelajaran menggunakan model pembelajaran BTL yang mengintegrasikan keterampilan pertanyaan tingkat tinggi, pemecahan masalah, pembelajaran kooperati, pemanfaatan lingkungan kelas, pemanfaatan media pembelajaran, dan lembar kerja. Pembelajaran dengan menggunakan model pembelajaran BTL akan meningkatkan aktivitas dan hasil belajar peserta didik.

\section{METODOLOGI PENELITIAN}

Subyek dalam penelitian ini adalah seluruh peserta didik kelas VIII G SMP1 Kudus pada semester 2 tahun pelajaran 2011/2012 yang berjumlah 26 peserta didik terdiri dari 14 peserta didik laki-laki dan 12 peserta didik perempuan. Sedangkan objek dalam penelitian ini adalah aktivitas belajar fisika, hasil belajar fisika, dan pemanfaatan model pembelajaran BTL.

Teknik yang digunakan untuk menganalisis ativitas belajar peserta didik dan guru meliputi data aktivitas belajar pada kondisi awal, data aktivitas belajar pada siklus 1 dan data aktivitas belajar pada siklus 2 dianalisis menggunakan teknik deskriptif komparatif dilanjutkan dengan refleksi. Sedangkan teknik yang digunakan untuk menganalisis data hasil belajar peserta didik yang meliputi data hasil belajar pada kondisi awal, data hasil belajar pada siklus 1 dan data hasil belajar pada siklus 2 dianalisis menggunakan teknik deskriptif komparatif dilanjutkan dengan refleksi. Refleksi, yaitu membuat simpulan berdasarkan deskriptif komparatif kemudian memberi ulasan atas simpulan tersebut untuk menentukan perlu tidaknya siklus berikutnya.

Indikator kinerja dalam penelitian ini dilihat dari peningka- 
tan aktivitas dan hasil belajar fisika melalui pembelajaran dengan model pembelajaran BTL. Indikator keberhasilan direfleksikan dengan: Peserta didik memperoleh nilai aktivitas belajar $\geq 85$ dan memperoleh nilai rata-rata hasil belajar $\geq 85$ pada akhir siklus.

Penelitian ini dilakukan menggunakan metode Penelitian Tindakan Kelas yang terdiri dari 2 siklus. Tindakan dalam setiap siklus saling berkaitan erat. Pada siklus 1 pembelajaran dilakukan dengan menggunakan model pembelajaran BTL dengan lembar kerja terbimbing dan media yang tersedia, sedangkan pada siklus 2 dengan memanfaatkan model pembelajaran BTL dengan lembar kerja terbuka dan media lingkungan sekitar. Siklus 1 dan 2 berlangsung pada 6 pertemuan (12 jam pelajaran). Variabel yang diteliti adalah pemanfaatan model pembelajaran BTL sebagai penyebab serta aktivitas belajar dan hasil belajar sebagai akibat.

Tahapan-tahapan dalam tiap siklus terdiri atas (1) membuat perencanaan tindakan (planning); (2) melaksanakan tindakan sesuai yang direncanakan (acting); (3) melaksanakan pengamatan terhadap tindakan yang dilaksanakan (observing); (4) menganalisis dengan deskriptif komparatif dilanjutkan dengan refleksi terhadap hasil pengamatan tindakan (reflecting).

\section{HASIL DAN PEMBAHASAN}

Hasil peningkatan aktivitas belajar fisika dari kondisi awal, siklus 1 dan siklus 2 tampak pada tabel 1 berikut.

\section{Tabel 1}

Aktivitas Belajar Kondisi Awal, Siklus 1 dan Siklus 2

\begin{tabular}{|c|c|c|c|}
\hline & $\begin{array}{c}\text { Kon d i s i } \\
\text { awal }\end{array}$ & Siklus 1 & Siklus 2 \\
\hline Aktivitas Peserta Didik & 64 & 78 & 94 \\
\hline Aktivitas Guru & 64 & 77 & 91 \\
\hline
\end{tabular}

Data aktivitas belajar tersebut dapat divisualisasikan pada gambar grafik 1 berikut. 


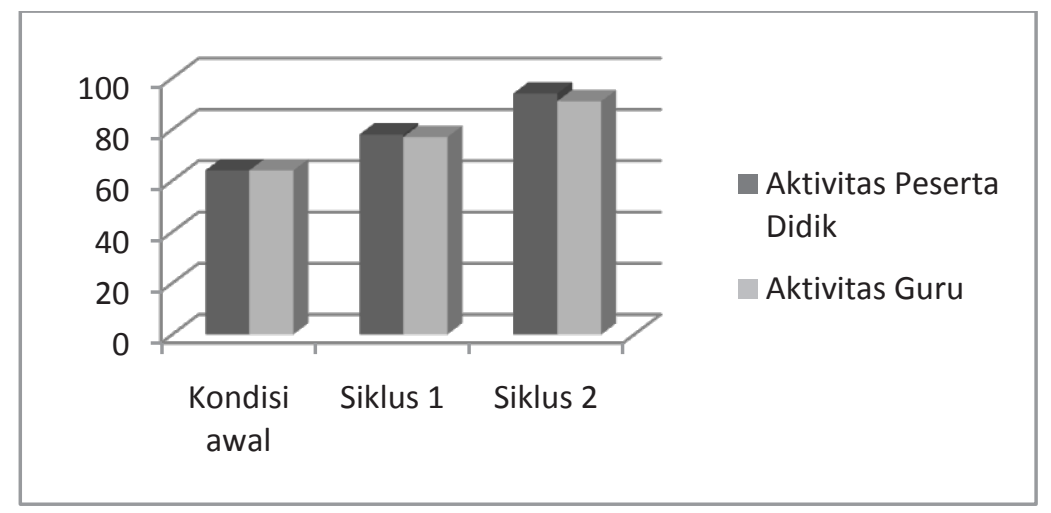

\section{Gambar 1}

Aktivitas Belajar Dari Kondisi Awal, Siklus 1 dan Siklus 2

Dari data tersebut terlihat terjadi peningkatan aktivitas belajar peserta didik dari 64 pada kondisi awal menjadi 78 pada siklus 1 dan 94 pada siklus 2. Terjadi peningkatan sebesar 14 angka antara kondisi awal dan siklus 1. Jika dibandingkan antara kondisi awal dan siklus 2 terjadi peningkatan 30 angka atau meningkat $49 \%$.

Hasil Peningkatan hasil belajar peserta didik dapat dilihat pada tabel berikut:

\section{Tabel 2}

Perbandingan Hasil Belajar Peserta Didik

\begin{tabular}{|c|c|c|c|}
\hline & Kondisi Awal & Siklus 1 & Siklus 2 \\
\hline Nilai Rata-rata & 72 & 81 & 88 \\
\hline
\end{tabular}

Data tersebut dapat divisualisasikan dengan gambar grafik 2 berikut. 


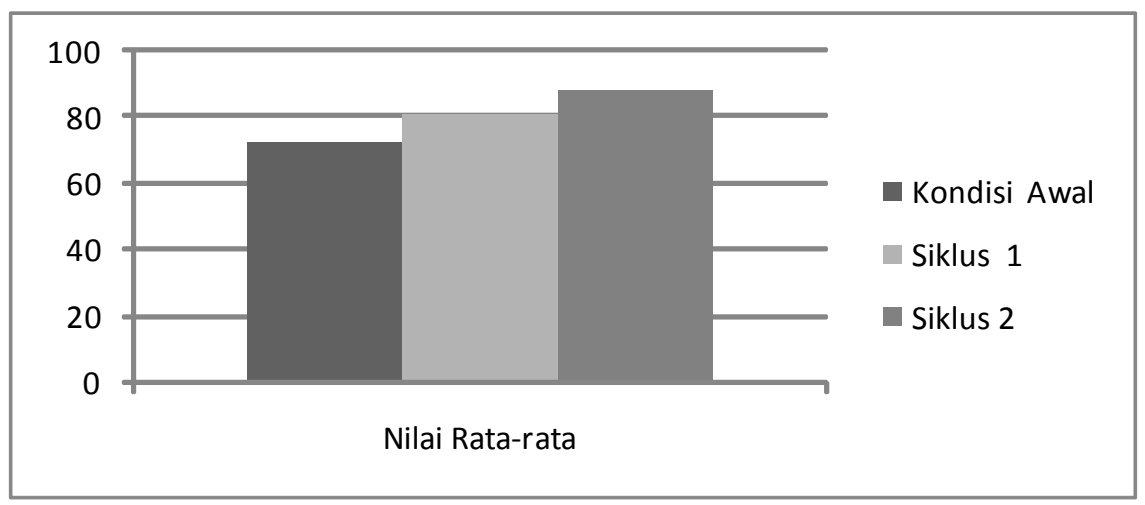

Gambar 2

\section{Perbandingan hasil belajar peserta didik}

Dari kondisi awal nilai rata-rata sebesar 72 meningkat menjadi 81 pada siklus 1 dan meningkat menjadi 88 pada siklus 2. Jika dibandingkan antara kondisi awal terjadi peningkatan 9 angka terhadap siklus 2. Jika dibandingkan antara kondisi awal dengan siklus 2 terjadi peningkatan 16 angka, atau terjadi kenaikan 22\%. Hal ini menunjukkan bahwa pemanfaatan model pembelajan BTL dapat meningkatkan hasil belajar peserta didik.

\section{PEMBAHASAN}

Hasil pengamatan aktivitas peserta didik dari kondisi awal sampai kondisi akhir (siklus 2) diamati dengan lembar observasi aktivitas peserta didik. Beberapa aktivitas peserta didik tersebut saat diamati pada kondisi awal, siklus 1 dan siklus 2 menunjukkan peningkatan. Peningkatan aktivitas belajar peserta didik dari 64 pada kondisi awal menjadi 78 pada siklus 1 dan 94 pada siklus 2. Terjadi peningkatan sebesar 14 angka antara kondisi awal dan siklus 1. Jika dibandingkan antara kondisi awal dan siklus 2 terjadi peningkatan 30 angka atau meningkat $49 \%$.

Model pembelajaran BTL mampu meningkatkan aktivitas belajar peserta didik karena dalam tahapan-tahapan pembelajaran dapat mengaktifkan seluruh aktivitas peserta didik. Secara umum aktivitas belajar fisika pada model pembelajaran BTL meliputi: melakukan 
instruksi guru, menjawab dan mebuat pertaanyaan, memanfaatkan perabot kelas dan lingkungan yang mendukung pembelajaran kooperatif, melakukan kerjasama kelompok, memanfaatkan lembar kerja dengan menggunakan media secara aktif dan menghasilkan hasil karya peserta didik sebagai sumber belajar.

Aktivitas peserta didik yang paling menonjol pada siklus 1 antara lain: pembelajaran kooperatif dengan bekerja secara kelompok, melaksanakan eksprimen dengan panduan lembar kerja terbuka yang terbimbing dan memanfaatkan media dan alat bahan yang tersedia di laboratorium. Sedangkan guru masih mendominasi memberi instruksi kerja. Pada siklus 2 dengan menggunakan lembar kerja terbuka, pada eksperimen peserta didik melakukan kegiatan yang mengeksplorasi aktivitas peserta didik, antara lain sebelum bereksperimen peserta didik merencanakan sendiri eksperimennya berdasarkan permasalahan pada LK, setelah itu dengan menggunakan alat dan bahan yang tersedia dan memanfaatkan lingkungan untuk menyelesaikan eksperimen tersebut.

Aktivitas peserta didik sangat beragam sesuai dengan karakteristik dan kualitas kerja kelompok dalam menyelesaikan masalah yang diberikan. Misalkan untuk memecahkan masalah dengan membaca tulisan terbalik, yang seharusnya dengan menggunakan cermin, ada kelompok yang membaca dengan menerawang tulisan tersebut. Begitu juga dengan membuat lubang pada kertas menggunakan bantuan sinar matahari dengan diameter seluas mungkin, ada kelompok yang melubangi kertas sedikit demi sedikit, ada juga yang menggunakan spidol hitam untuk membuat warna hitam pada kertas sehingga mempercepat terjadinya lubang. Keberagaman aktivitas peserta didik inilah yang menunjukkan keberhasilan model ini.

Hasil belajar fisika yang diperoleh dari nilai tes tertulis juga menunjukkan peningkatan dari kondisi awal, siklus 1 dan siklus 2. Dengan kondisi awal nilai rata-rata hasil belajar 72 masih berada di bawah KKM, sehingga dibutuhkan remidial teaching dan remidial testing untuk mencapai nilai KKM. Sehingga nilai rata-rata hasil belajar di atas KKM pada siklus berikutnya.

Dari kondisi awal nilai rata-rata sebesar 72 meningkat men- 
jadi 81 pada siklus 1 dan meningkat menjadi 88 pada siklus 2. Jika dibandingkan antara kondisi awal terjadi peningkatan 9 angka terhadap siklus 2. Jika dibandingkan antara kondisi awal dengan siklus 2 terjadi peningkatan 16 angka, atau terjadi kenaikan 22\%. Hal ini menunjukkan bahwa pemanfaatan model pembelajan BTL dapat meningkatkan hasil belajar peserta didik.

\section{SIMPULAN}

Berdasarkan hasil analisis disimpulkan bahwa aktivitas belajar peserta didik meningkat setelah dibelajarkan dengan model pembelajaran BTL yang mengintegrasikan keterampilan pertanyaan tingkat tinggi, pemecahan masalah, pembelajaran kooperatif, pemanfaatan lingkungan kelas, media pembelajaran dan penilaian. Peningkatan aktivitas belajar peserta didik sebasar $49 \%$, dari kondisi awal 64 menjadi 94 pada kondisi akhir. Dan hasil belajar peserta didik meningkat setelah dibelajarkan dengan model pembelajaran BTL yang mengintegrasikan keterampilan pertanyaan tingkat tinggi, pemecahan masalah, pembelajaran kooperatif, pemanfaatan lingkungan kelas, media pembelajaran dan penilaian. Peningkatan hasil belajar peserta didik sebesar $22 \%$, dari kondisi awal 72 menjadi 88 pada kondisi akhir. 


\section{DAFTAR PUSTAKA}

DBE3. 2009. Modul Pelatihan Pengajaran Profesional dan Pembelajaran Bermakna 2. Jakarta: DBE3

DBE3. 2009. Modul Pelatihan Pengajaran Profesional dan Pembelajaran Bermakna 3. Jakarta: DBE3.

Hamalik, O. 2007. Proses Belajar Mengajar. Bandung: PT Bumi Aksara.

Indrawati. 2000. Model-model Pembelajaran IPA. Bandung: PPPG IPA.

Permendiknas No 22, 23 dan 24 tahun 2006. Jakarta: Depdiknas.

Permendiknas No. 41 tahun 2007. Jakarta: Depdiknas

Rochim, A. 2011. "Keefektifan Model Pembelajaran Better Teaching and Learning (BTL) dalam Membelajarkan Alat Optik". Tesis. PPs UNNES

Rosmawati, 2011. "Pemanfaatan Lingkungan sebagai Sumber Belajar untuk Meningkatkan Minat Belajar Siswa". Jurnal PTK DBE3. Volume Khusus/1: 49-56

Sugiyono. 2009. Metode Penelitian Pendidikan: Pendekatan Kuantitatif, Kualitatif dan REDD. Bandung: Penerbit Alfabet.

Wiyanto. 2008. Menyiapkan Guru Sains Mengembangkan Kompetensi Laboratorium. Semarang: Universitas Negeri Semarang Press. 